\title{
KAJIAN PERFORMANSI MESIN DIESEL 1 SILINDER MENGGUNAKAN BAHAN BAKAR CAMPURAN SOLAR DAN BIODIESEL MINYAK KANOLA DENGAN HI-CESTER
}

David Firdaus Bijaksana Sianturi ${ }^{1}$, Dr. Tulus Burhanuddin Sitorus, ST., MT . ${ }^{2}$ Departemen Teknik Mesin, Fakultas Teknik, Universitas Sumatera Utara davidfiesxa@gmail

\begin{abstract}
Along with the rapid development of technology, an enormous source of energy is also required. Aside from using energy sources that originate from fossil fuel, it is also possible to use biodiesel fuel as the primary fuel. This study utilizes biodiesel fuel from raw material of canola oil and HI-Cester. The objective of this study in addition to figuring out the effect towards machine performance, also to calculate the emission of exhaust gasses. This method of the study is started by testing the heat value of the fuel, which is B10, B20, B30, B40, Solar 100\%, B10 + HI-Cester $0.5 \mathrm{ml}, \mathrm{B} 20+$ HI-Cester $0.5 \mathrm{ml}$, B30 + HI-Cester 0.5 $\mathrm{ml}, \mathrm{B} 40+\mathrm{HI}$-Cester $0.5 \mathrm{ml}$, and solar 100\% + HI-Cester. The amount of O2 gas exhaust emission undergoes a decrease but an increase occurs if HI-Cester is added. NOx exhaust emission undergoes decrease when using only biodiesel as well as if HI-Cester is added. $\mathrm{CO}$ exhaust emission undergoes an increase. $\mathrm{CO} 2$ undergoes an increase if only using biodiesel and undergoes a decrease after HI-Cester is added. Experimental data shows that the maximum power acquired is 2,20 kW and actual maximum thermal efficiency is $36,03 \%$ when solar fuel is used, specific fuel consumption 628,496 $\mathrm{g} / \mathrm{kWh}$. Highest average temperature of combustion chamber is achieved by solar fuel 100\% + HI-Cester with the amount of $197,37^{\circ} \mathrm{C}$ and the lowest is achieved by B20 fuel with the amount of $183,37^{\circ} \mathrm{C}$.
\end{abstract}

Keywords : Canola biodiesel, diesel engine, HI-Cester

\begin{abstract}
ABSTRAK
Seiring perkembangan teknologi, dibutuhkan sumber energi yang besar pula. Selain menggunakan sumber energi dari bahan bakar fosil, dapat juga menggunakan bahan bakar biodiesel sebagai bahanbakar utama. Penelitian ini menggunakan bahan bakar biodiesel dengan bahan baku minyak kanola dan HI-Cester. Tujuan penelitian ini selain untuk mengetahui pengaruh terhadap performansi mesin dan emisi gas buang yang dihasilkan. Metode penelitian diawali dengan pengujian nilai kalor bahan bakar yaitu B10, B20, B30, B40, Solar 100\%, B10 + HI-Cester 0.5 ml, B20 + HI-Cester 0.5 ml, B30 + HI-Cester 0.5 $\mathrm{ml}$, B40 + HI-Cester $0.5 \mathrm{ml}$, dan solar 100\% + HI-Cester. Besarnya emisi gas buang $\mathrm{O} 2$ mengalami penurunan dan jika ditambah $\mathrm{HI}$-Cester kandungannya meningkat. NOx mengalami penurunan saat menggunakan bahan bakar biodiesel saja maupun ditambah $\mathrm{HI}$ Cester. CO mengalami pengingkatan. CO2 mengalami peningkatan jika bahan bakar hanya menggunakan biodiesel dan mengalami penurunan setelah ditambah HI-Cester. Data eksperimental menunjukkan bahwa daya maksimum diperoleh 2,20 kW dan efisiensi termal aktual maksimum 36,03\% saat menggunakan bahan bakar solar, konsumsi bahan bakar spesifik 628,496 $\mathrm{g} / \mathrm{kWh}$. Temperatur ruang bakar rata-rata tertinggi dicapai oleh bahan bakar Solar $100 \%+\mathrm{HI}$-Cester sebesar $197,37^{\circ} \mathrm{C}$ dan yang terendah dicapai oleh bahan bakar B20 sebesar $183,37^{\circ} \mathrm{C}$.
\end{abstract}

Kata kunci : Biodiesel kanola, mesin diesel, HI-Cester 


\section{PENDAHULUAN}

Perkembangan teknologi di dunia dari waktu ke waktu semakin berkembang. Seiring perkembangan, diperlukan juga asupan sumber energi yang besar. Suatu saat akan tiba saatnya sumber energi tersebut habis. Umumnya sumber energi yang sering digunakan pada mesin adalah bahan bakar yang berasal dari pelapukan tumbuhan dan hewan yang telah mati ribuan hingga jutaan tahun yang lalu. Agar dapat meminimalisir penggunaan bahan bakar minyak, maka dibutuhkan sumber energi yang lain atau melakukan pengefesiensian energi. Bahan bakar minyak (BBM) saat sekarang ini menjadi salah satu permasalahan bagi Indonesia. Kebutuhan bahan bakar minyak di Indonesia tiap tahun semakin naik. Itu berarti juga perkembangan teknologi di Indonesia meningkat. Yang mengakibatkan pemerintah Indonesia harus mencari jalan lain untuk mengatasi kebutuhan tersebut. Menggunakan bahan bakar alternatif adalah salah satu cara untuk mengatasi permasalahan tersebut. Salah satu bahan bakar alternatif yang diharapkan menjadi terobosan di masa depan yaitu biodiesel.

\section{TEORI DASAR}

\subsection{Mesin Diesel}

Mesin diesel yang biasa disebut juga dengan mesin pemicu kompresi adalah motor bakar jenis pembakaran dalam yang menggunakan hasil kompresi untuk menciptakan nyala api dan membakar bahan bakar yang sudah diinjeksikan ke dalam ruang bakar. Motor bakar adalah mesin yang mengubah energi termal/panas menjadi energi mekanis atau mengubah energi kimia dari bahan bakar menjadi energi gerak. Motor bakar pembakaran dalam adalah sebuah mesin yang asal tenaganya berasal dari pengembangan gas panas bertekanan tinggi hasil dari pembakaran campuran antara bahan bakar dan udara yang terjadi di dalam ruang tertutup pada mesin yang biasa disebut dengan ruang bakar (combution chamber).

\subsubsection{Prinsip Kerja Mesin Diesel}

Pada dasarnya prinsip kerja mesin diesel 2 langkah dan 4 langkah tidak jauh berbeda dengan prinsip kerja mesin otto, tetapi yang membedakan cara masuknya bahan bakar. Berikut ini adalah langkah-langkah cara kerja mesin diesel 4 langkah :

1. Langkah hisap

Pada langkah ini piston bergerak dari Titik Mati Atas (TMA) ke Titik Mati Bawah (TMB). Saat piston bergerak ke bawah, katup hisap terbuka sehingga menyebabkan tekanan dalam ruang bakar menurun lebih dari rendah dari tekanan atmosfir yang mengakibatkan udara masuk ke dalam ruang bakar melalui filter udara. 


\section{Langkah kompresi}

Pada langkah ini piston bergerak dari TMB ke TMA dan kedua katup tertutup. Udara yang berada di dalam ruang bakar ditekan atau dikompres sehingga tekanan dan temperatur meningkat. Beberapa saat sebelum piston mencapai TMA, bahan bakar disemprotkan ke dalam ruang bakar.

3. Langkah kerja

Semprotan bahan bakar di ruang bakar akan menyebabkan ledakan pembakaran yang menyebabkan tekanan dan temperatur semakin meningkat. Ledakan tersebut akan mendorong piston dari TMA ke TMB sehingga terjadinya gaya aksial. Gaya aksial tersebut diteruskan oleh poros engkol menjadi gaya putar.

4. Langkah buang

Pada langkah ini gaya sentripetal yang masih berlangsung pada flywheel akan menaikkan kembali piston dari TMB ke TMA, pada bersamaan itu juga katup buang terbuka sehingga udara sisa pembakaran akan didorong keluar dari ruang bakar menuju exhaust manifold kemudian diteruskan menuju knalpot. Siklus ini berlangsung secara kontinu sehingga pergerakan dari piston pun tidak berhenti selama faktor pendukung, yaitu udara, bahan bakar, dan sumber api selalu tersedia.

\subsubsection{Teori Pembakaran}

Pembakaran merupakan suatu proses reaksi kimia dari bahan bakar yang setelah dinyalakan dan digabung dengan oksigen akan menghasilkan panas yang dapat meningkatkan temperatur dan tekanan. Elemen utama dari bahan bakar yang dapat terbakar adalah karbon (C) dan hidrogen $(\mathrm{H})$, namun ada elemen lain yang terkandung dalam bahan bakar tetapi sedikit, yaitu sulfur (S). Oksigen yang diperlukan untuk proses pembakaran diperoleh dari udara bebas yang merupakan campuran dari oksigen dan nitrogen.

\subsubsection{Emisi Gas Buang}

a. Karbon monoksida (CO)

Karbon monoksida, adalah gas yang tak berwarna, tak berbau, dan tak berasa. Karbon monoksida dihasilkan dari pembakaran tak sempurna dari senyawa karbon yang terdapat dalam bahan bakar, sering terjadi pada mesin pembakaran dalam. Karbon monoksida terbentuk apabila terdapat kekurangan oksigen dalam proses pembakaran.

b. Karbon dioksida $\left(\mathrm{CO}_{2}\right)$

Karbon dioksida adalah gas yang tidak berwarna dan tidak berbau. Sebagai hasil pembakaran dari karbon dan oksigen dapat bergabung membentuk senyawa karbon dioksida $\left(\mathrm{CO}_{2}\right)$ akibat dari pembakaran yang sempurna dan pembakaran yang tidak sempurna akan menghasilkan senyawa karbon monoksida (CO). 
c. $\mathrm{NO}_{\mathrm{x}}$

Gas ini dihasilkan dari reaksi antara nitrogen dan oksigen di udara saat pembakaran, terutama pada suhu tinggi. Di tempat-tempat dengan kepadatan lalu lintas yang tinggi, seperti di kota-kota besar, jumlah nitrogen oksida yang dilepaskan ke udara sebagai polusi udara dapat meningkat signifikan.

\subsubsection{Performansi Mesin Diesel}

\section{Nilai Kalor Bahan Bakar}

Reaksi antara bahan bakar dengan oksigen dari udara akan menghasilkan panas. Besarnya panas yang dihasilkan jika satu satuan bahan bakar yang dibakar sempurna disebut nilai kalor bahan bakar (Calorific Value / CV).

Secara teoritis, besarnya nilai kalor atas (HHV) dapat dihitung dengan persamaan Dulong di bawah ini:

$$
H H V=33950 C+144200\left(H_{2}-\frac{O_{2}}{8}\right)+9400 S
$$

Dimana: $\quad H H V=$ nilai kalor atas $(\mathrm{kJ} / \mathrm{kg})$

$\mathrm{C} \quad=$ persentase karbon dalam bahan bakar

$\mathrm{H}_{2} \quad$ = persentase hidrogen dalam bahan bakar

$\mathrm{O}_{2} \quad$ = persentase oksigen dalam bahan bakar

$S \quad=$ persentase sulfur dalam bahan bakar

Nilai kalor bawah (Low Heating Value / LHV) merupakan nilai kalor bahan bakar tanpa panas laten yang berasal dari pengembunan uap air. Panas laten pengkondensasian uap air pada tekanan parsial $20 \mathrm{kN} / \mathrm{m}^{2}$ (tekanan yang umum timbul pada gas buang) adalah sebesar 2400 $\mathrm{kJ} / \mathrm{kg}$, sehingga besarnya nilai kalor bawah ( $L H V$ ) dapat dihitung berdasarkan persamaan berikut:

$$
L H V=H H V-2400\left(\mathrm{M}+9 H_{2}\right)
$$

Dimana: $\quad L H V \quad=$ nilai kalor bawah $(\mathrm{kJ} / \mathrm{kg})$

M = persentase air dalam bahan bakar

Dalam menghitung efisiensi panas dari motor bakar dapat menggunakan nilai bawah kalor bahan bakar ( $L H V)$ dengan berasumsi suhu tinggi yang meninggalkan mesin tidak terjadi pengembunan uap air.

\section{Daya}

Besarnya kerja mesin dalam suatu waktu disebut daya. Daya yang dapat dihasilkan merupakan salah satu prestasi motor bakar. Semakin tinggi putaran motor, semakin tinggi pula daya yang diberikan hal ini dikarenakan langkah kerja yang bertambah banyak pada satu waktu. Dengan demikian besarnya daya dapat diperoleh dengan menggunakan persamaan: 


$$
P_{b}=\frac{2 \pi(n \times T)}{6000}
$$

Dimana: $\quad P_{b} \quad=$ daya $(\mathrm{kW})$

$$
\begin{array}{ll}
T & =\operatorname{torsi}(\mathrm{Nm}) \\
n & =\operatorname{putaran}(\mathrm{rpm})
\end{array}
$$

\section{Torsi}

Torsi merupakan perkalian antara vektor dari axis putaran dengan gaya. Selama langkah kerja, tekanan yang terjadi di dalam silinder motor menimbulkan suatu gaya pada torak. Gaya tersebut dipindahkan ke pena engkol (crank pin) melalui connecting rod yang mengakibatkan adanya torsi atau momen putar pada poros engkol (crankshaft). Alat yang biasa digunakan menghitung torsi adalah dynamometer. Untuk mencari besarnya torsi dapat menggunakan persamaan dibawah ini:

$$
T=\frac{P_{b} \times 6000}{2 \pi} \times n
$$

Dimana: $\quad P_{b} \quad=$ daya $(\mathrm{kW})$

$$
\begin{array}{ll}
T & =\text { torsi }(\mathrm{Nm}) \\
n & =\operatorname{putaran}(\mathrm{rpm})
\end{array}
$$

\section{Rasio udara-bahan bakar (AFR)}

Rasio udara-bahan bakar merupakan perbandingan massa udara yang digunakan sebagai bahan untuk pembakaran di dalam silinder. Jika jumlah udara yang dimasukkan benar-benar persis cukup untuk membakar semua bahan bakar, perbandingan ini disebut dengan campuran stoikiometri, biasa disebut stoich. Besar dari AFR yang ideal untuk solar adalah sebesar 14,5. Sementara untuk menghitung AFR secara aktual dapat menggunakan persamaan:

$$
A F R=\frac{\dot{m}_{a}}{\dot{m}_{f}}
$$

Dimana: $\quad A F R \quad=$ air fuel ratio

$$
\begin{array}{ll}
\dot{\mathrm{m}}_{\mathrm{a}} & =\text { laju aliran massa udara }(\mathrm{kg} / \mathrm{s}) \\
\dot{\mathrm{m}}_{\mathrm{f}} & =\text { laju aliran massa bahan bakar }(\mathrm{kg} / \mathrm{s})
\end{array}
$$

\section{Efisiensi volumetris}

Efisiensi volumetris merupakan salah satu parameter prestasi mesin untuk mengukur efektifitas udara atau campuran udara-bahan bakar yang dapat dihisap ke dalam ruang bakar. Semakin besar efisiensi volumetris, maka semakin banyak udara atau campuran udara-bahan bakar yang dapat dimasukkan ke dalam ruang bakar sehingga tenaga yang dihasilkan pun lebih besar. Efisiensi volumetris dapat dihitung menggunakan persamaan:

$$
\eta_{v}=\frac{2 \dot{m}_{a}}{60 n} \times \frac{1}{\rho_{a} V_{s}}
$$

Dimana: $\quad \dot{\mathrm{m}}_{\mathrm{a}} \quad=$ laju aliran massa udara $(\mathrm{kg} / \mathrm{s})$

$$
\rho_{\mathrm{a}} \quad=\text { kerapatan udara }\left(\mathrm{kg} / \mathrm{m}^{3}\right)
$$




$$
\begin{aligned}
V_{s} & =\text { volume langkah torak }\left(\mathrm{m}^{3}\right) \\
& =0.00023 \text { (berdasarkan spesifikasi mesin) }
\end{aligned}
$$

Diasumsikan udara sebagai gas ideal sehingga massa jenis udara dapat diperoleh menggunakan persamaan:

$$
\rho_{\mathrm{a}}=\frac{P}{R T_{a}}
$$

Dimana: $\quad \mathrm{R} \quad=$ konstanta gas $(287 \mathrm{~J} / \mathrm{kgK})$

\section{Daya Aktual}

Besarnya kerja mesin dalam suatu waktu yang dikalikan dengan efisiensi volumetris dan efisiensi mekanis disebut dengan daya aktual. Dengan demikian besarnya daya aktual dapat diperoleh dengan menggunakan persamaan:

$$
\mathrm{P}_{\mathrm{a}}=\mathrm{P}_{\mathrm{b}} \times \eta_{\mathrm{v}} \times \eta_{\mathrm{m}}
$$

Dimana: $\quad P_{b} \quad=$ daya pembacaan $(\mathrm{kW})$

$\eta_{\mathrm{v}} \quad=$ efisiensi volumetris

$\eta_{\mathrm{m}} \quad=$ efisiensi mekanis

Untuk mesin diesel efisiensi mekanisnya sebesar 0,75-0,95

\section{Efisiensi termal aktual}

Kerja berguna yang dihasilkan selalu lebih kecil daripada energi input yang dibangkitkan oleh torak yang disebabkan oleh adanya rugi-rugi mekanis (mechanic losses). Oleh sebab itu perlu dicari jumlah kerja berguna terhadap energi yang dihasil dari pembakaran bahan bakar, dapat dicari menggunakan persamaan berikut:

$$
\eta_{t}=\frac{P_{a}}{\dot{m}_{f} \times L H V} \times 3600
$$

Dimana: $\quad \eta_{t} \quad=$ efisiensi termal

$$
\begin{array}{ll}
\dot{\mathrm{m}}_{\mathrm{f}} & =\text { laju aliran massa bahan bakar }(\mathrm{kg} / \mathrm{s}) \\
P_{a} & =\text { daya aktual }(\mathrm{W}) \\
L H V & =\text { niai kalor bawah }
\end{array}
$$

\section{Konsumsi bahan bakar spesifik (SFC)}

Konsumsi bahan bakar dibandingkan dengan daya mesin yang dihasilkan dalam jarak waktu tertentu dikenal dengan istilah konsumsi bahan bakar spesifik atau spesific fuel comsumption (SFC). Konsumsi bahan bahan bakar spesifik ini merupakan indikator keefektifan dari suatu motor bakar dalam penggunaan atau konsumsi pemakaian bahan bakar untuk menghasilkan daya motor. Besarnya SFC dapat dihitung menggunakan persamaan dibawah ini:

$$
S F C=\frac{\dot{m}_{f} \times 10^{3}}{P_{a}}
$$




$$
\dot{m}_{f}=\frac{s g f \times v_{f} \times 10^{-3}}{t} \times 3600
$$

Dimana: $\quad$ SFC $\quad=$ konsumsi bahan bakar spesifik $(\mathrm{gr} / \mathrm{kWh})$

$$
\begin{array}{ll}
P_{a} & =\text { daya }(\mathrm{W}) \\
v_{f} & =\text { volume bahan bakar yang dikonsumsi (ml) } \\
\dot{m}_{f} & =\text { laju aliran bahan bakar (gr/jam) } \\
\text { sgf } & =\text { gravitasi spesifik bahan bakar } \\
t & =\text { waktu (s) }
\end{array}
$$

\section{Temperatur ruang bakar}

Pada langkah piston bergerak dari TMB ke TMA dan kedua katup tertutup. Udara yang berada di dalam ruang bakar ditekan atau dikompres sehingga tekanan dan temperatur meningkat. Beberapa saat sebelum piston mencapai TMA, bahan bakar disemprotkan ke dalam ruang bakar. Temperatur ruang bakar mesin diesel pada langkah ini bisa sampai suhu $550{ }^{\circ} \mathrm{C}$.

\subsection{Biodiesel}

Biodiesel merupakan salah satu bentuk energi terbarukan yang ramah lingkungan, tidak mempunyai efek terhadap kesehatan dan memiliki emisi gas yang lebih baik dari pada bahan bakar minyak. Biodiesel mempunyai sifat pembakaran yang serupa dengan solar atau bahan bakar diesel lainnya sehingga dapat digunakan langsung ke mesin tanpa harus memodifikasi mesin terlebih dahulu. Biodiesel dapat digunakan dengan mudah karena dapat langsung bercampur dengan bahan bakar lain seperti solar karena memiliki sifat fisik yang hampir sama dan dapat langsung diaplikasikan ke mesin-mesin diesel tanpa memodifikasi, asap buangan juga tidak hitam, tidak mengandung sulfur sehingga emisi pembakaran yang dihasilkan ramah lingkungan.

\section{$2.3 \quad$ Vitamin HI-Cester}

Vitamin HI-Cester merupakan zat aditif yang mampu menyempurnakan pembakaran karena dapat meningkatkan cetane number. Cetane number merupakan standar untuk mengukur kemampuan bahan bakar untuk terbakar secara spontan. Cetane merupakan senyawa kimia yang dikenal dengan juga dengan nama heksadekana. Senyawa ini bisa menyala secara spontan karena adanya tekanan. Semua bahan bakar diesel diklasifikasikan berdasarkan bilangan cetane karena kemampuannya untuk memunculkan nyala api dalam kondisi tekanan tinggi. Bilangan cetane mengukur seberapa cepat bahan bakar mulai untuk terbakar dalam mesin bertekanan ${ }^{[8]}$. Adapun kegunaan daripada vitamin HI-Cester adalah mengoptimalkan pembakaran mesin diesel, menghemat konsumsi bahan bakar, mengurangi kadar emisi gas buang $\mathrm{CO}_{2}$, dan mesin lebih bertenaga. 


\section{HASIL DAN PEMBAHASAN}

\subsection{Set Up Alat}

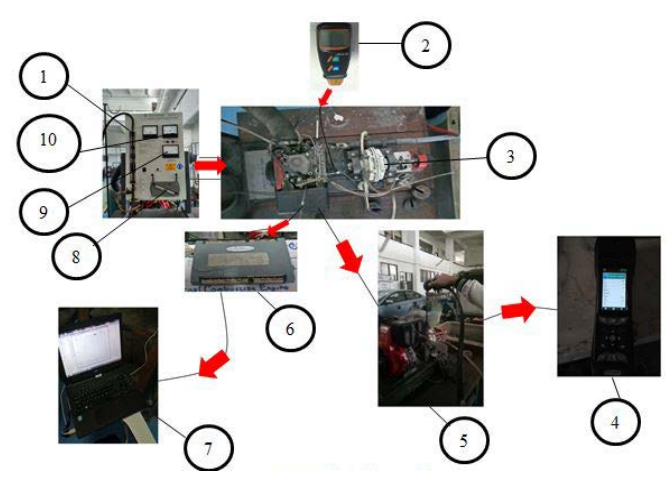

Gambar 3.1 Set up alat

Keterangan gambar :

1. Flow meter bahan bakar

2. Tachometer

3. Dynamometer

4. E Instrument E4500-3 Gas Combustion Analyzer

5. Sensor Gas Combustion Analyzer

6. Termokopel

7. Laptop

8. Manometer

9. Exhaust temperatur

10. Torsimeter

\subsection{Hasil Pengujian dan Analisis}

\subsubsection{Laju aliran bahan bakar (mf)}

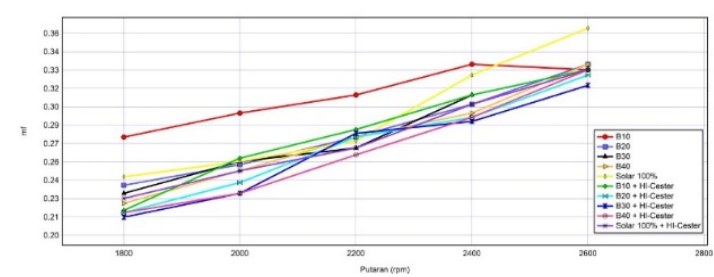

Gambar 3.2 Grafik nilai $\dot{m}_{\mathrm{f}}$ vs putaran pada pembebanan 3,5 kg 


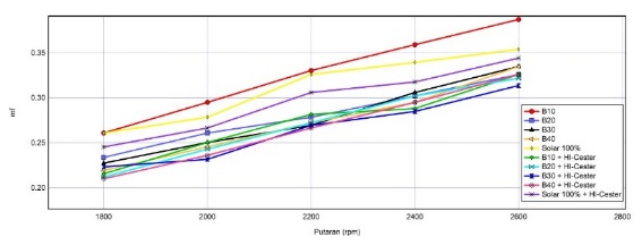

Gambar 3.3 Grafik nilai $\dot{m}_{\mathrm{f}}$ vs putaran pada pembebanan 4,5 kg

Dari grafik di atas pembebanan 3,5 kg dan 4,5 kg, terlihat bahwa nilai $\mathrm{m}$ f dipengaruhi putaran dan waktu pembakaran bahan bakar. Semakin tinggi putaran dan waktu pembakaran bahan bakar semakin rendah, maka mf semakin tinggi.

\subsubsection{Rasio udara-bahan bakar}

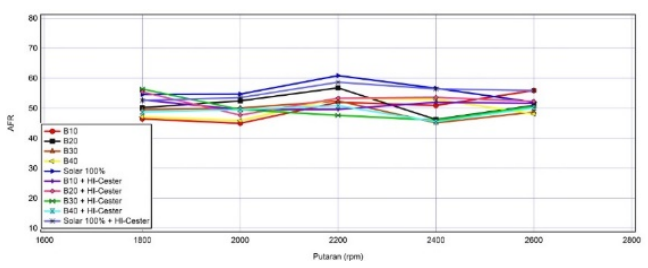

Gambar 3.4 Grafik nilai AFR vs putaran pada pembebanan 3,5 kg

Dari grafik di atas dapat dilihat pada putaran 2000 rpm dan 2400 rpm cenderung menurun karena pada putaran tersebut waktu pembakaran disetiap variasi bahan bahan bakar cenderung menurun.

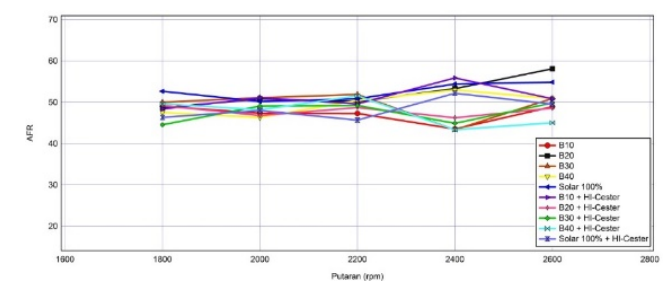

Gambar 3.5 Grafik nilai $A F R$ vs putaran pada pembebanan $4,5 \mathrm{~kg}$

Dari grafik di atas dapat dilihat pada putaran dan 2400 rpm cenderung menurun karena pada putaran tersebut waktu pembakaran disetiap variasi bahan bakar menurun.

\subsubsection{Efisiensi volumetris}

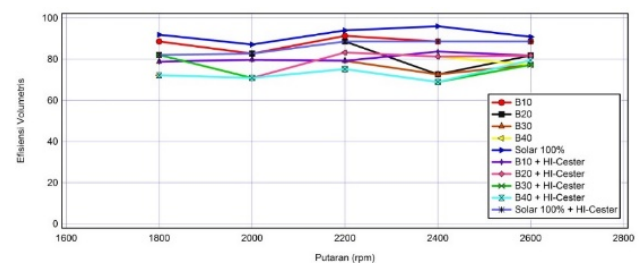

Gambar 3.6 Grafik efisiensi volumetris vs putaran pada pembebanan 3,5 kg

Dari grafik di atas dapat diketahui nilai efisiensi volumetris bahan bakar B30 + HI-Cester, B10, dan solar 100\% pada putaran 2000 rpm dan dan bahan bakar B20, B30, dan B40 + HI-Cester pada putaran 2400 rpm cenderung menurun karena nilai hasil pengukuran manometer tidak sebanding dengan putaran nya. 


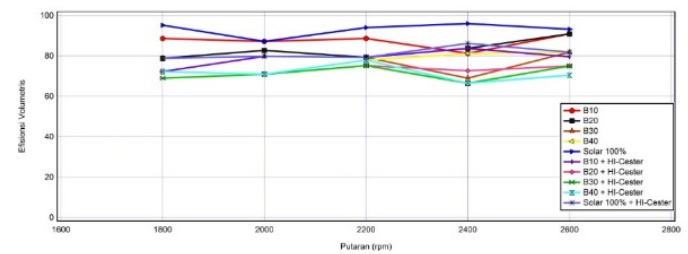

Gambar 3.7 Grafik efisiensi volumteris vs putaran pada pembebanan 4,5 kg

Dari grafik di atas dapat diketahui pada nilai efisiensi volumetris cenderung meningkat tetapi bahan bakar B10, B30, B30 + HI-Cester, dan B40 + HI-Cester pada putaran 2400 rpm, efisiensi volumetris cenderung menurun yang disebabkan oleh nilai hasil pengukuran manometer tidak sebanding dengan putaran nya.

\subsubsection{Daya aktual}

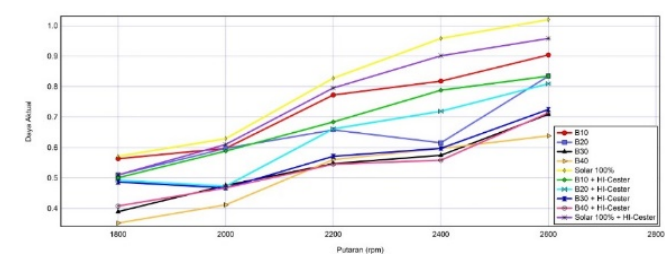

Gambar 3.8 Grafik daya aktual vs putaran pada pembebanan 3,5 kg

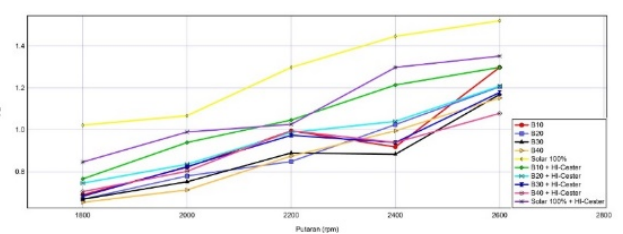

Gambar 3.9 Grafik daya aktual vs putaran pada pembebanan 4,5

Dari grafik di atas dapat dilihat bahwa solar memiliki nilai daya aktual yang terbesar dari hampir semua variasi bahan bakar yang ada, ini disebabkan solar memiliki nilai kalor paling tinggi dari semua variasi yang ada dan meningkat saat putaran mesin dinaikkan.

\subsubsection{Efisiensi Termal Aktual}

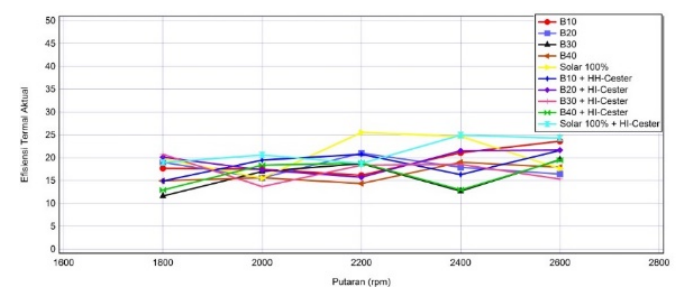

Gambar 3.10 Grafik efisiensi termal aktual vs putaran pada pembebanan 3,5 kg

Dari grafik di atas dapat dilihat bahan bakar Solar 100\%, B30 + HI-Cester, dan B20 + HICester pada putaran 2000 rpm cenderung menurun disebabkan oleh waktu pembakaran yang lebih cepat. 


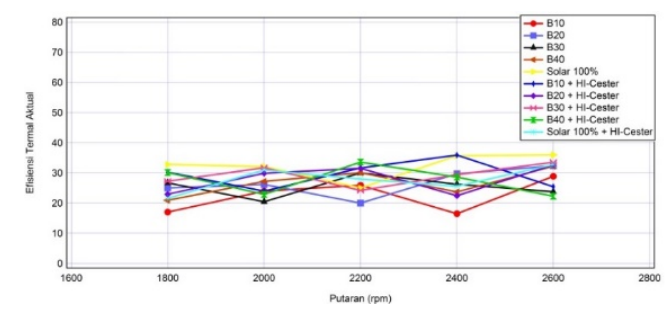

Gambar 3.11 Efisiensi termal aktual vs putaran pada pembebanan 4,5 kg

Dari grafik di atas dapat dilihat nilai efisiensi termal tiap varian bakar mengalami fluktuasi disebabkan oleh pada pembebanan 4,5 kg waktu pembakaran antara tiap bahan bakar tidak konstan.

\subsubsection{Konsumsi bahan bakar spesifik (SFC)}

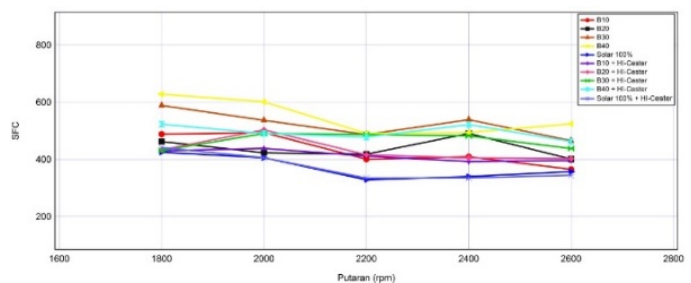

Gambar 3.12 Grafik SFC vs putaran pada pembebanan 3,5 kg

Dari grafik di atas dapat dilihat bahwa semakin tinggi putaran, maka nilai SFC cenderung menurun yang disebabkan oleh daya aktual yang semakin besar jika putaran mesin semakin tinggi.

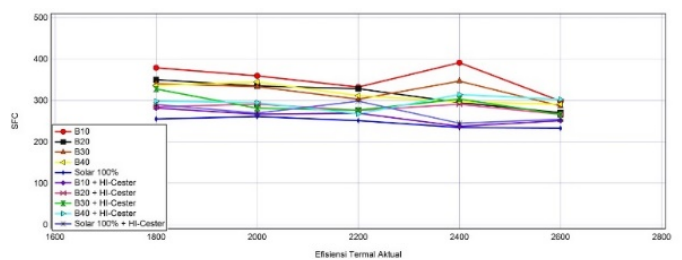

Gambar 3.13 Grafik $S F C$ vs putaran pada pembebanan 4,5 kg

Dari grafik di atas dapat dilihat bahwa nilai SFC cenderung menurun yang disebabkan oleh daya aktual yang semakin besar jika putaran mesin semakin tinggi.

\subsubsection{Temperatur Ruang Bakar}

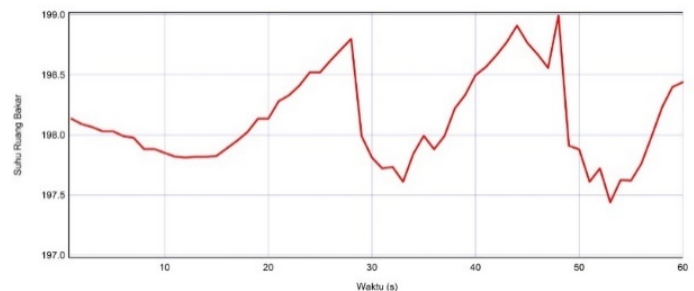

Gambar 3.14 Grafik suhu ruang bakar B10 vs waktu 


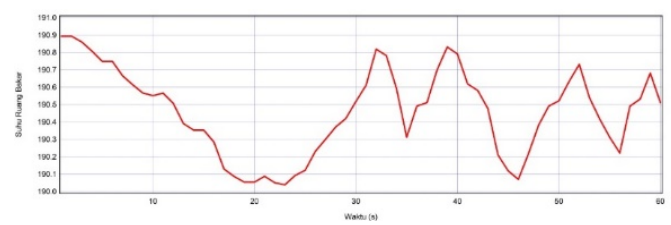

Gambar 3.16 Grafik suhu ruang bakar B30 vs waktu

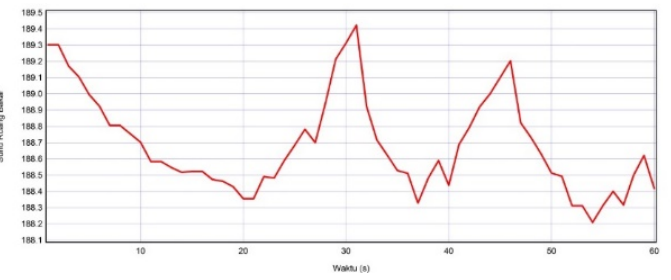

Gambar 3.17 Grafik temperatur ruang bakar B40 vs waktu

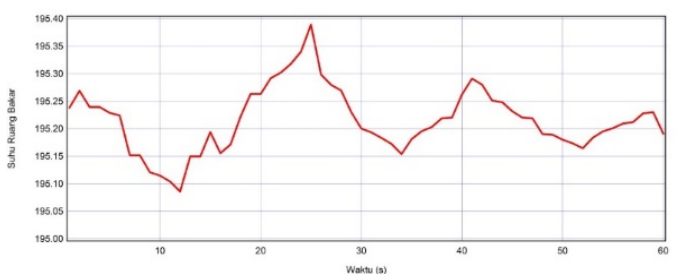

Gambar 3.18 Grafik suhu ruang bakar Solar 100\% vs waktu

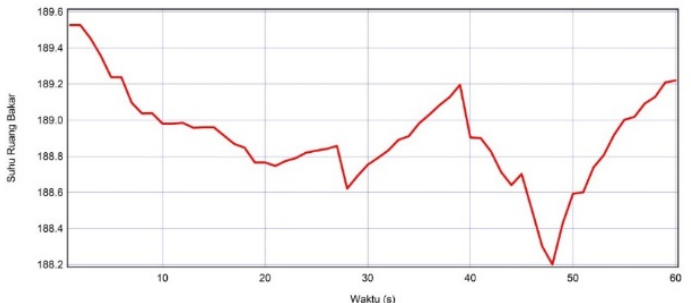

Gambar 3.19 Grafik suhu ruang bakar B10 + HI-Cester vs waktu

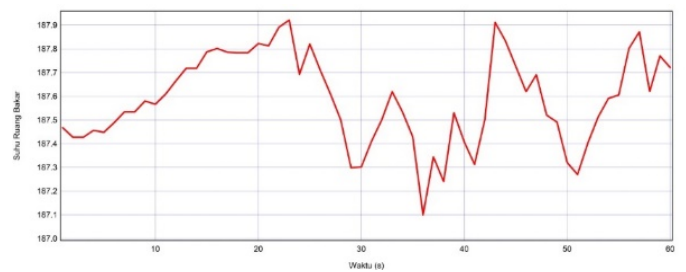

Gambar 3.20 Grafik temperatur ruang bakar B20 + HI-Cester vs waktu

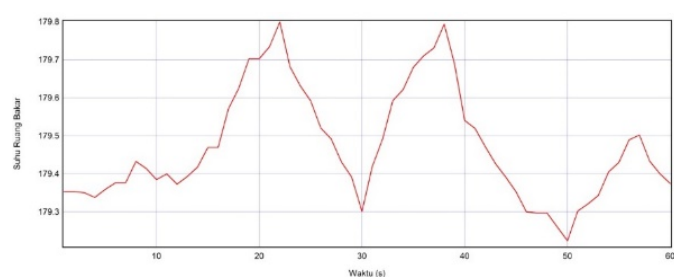

Gambar 3.21 Grafik temperatur ruang bakar B30 + HI-Cester vs waktu

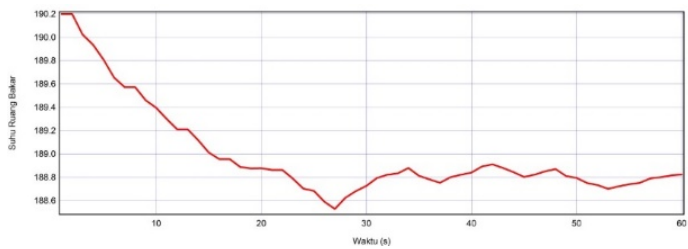

Gambar 3.21 Grafik temperatur ruang bakar B40 + HI-Cester vs waktu 


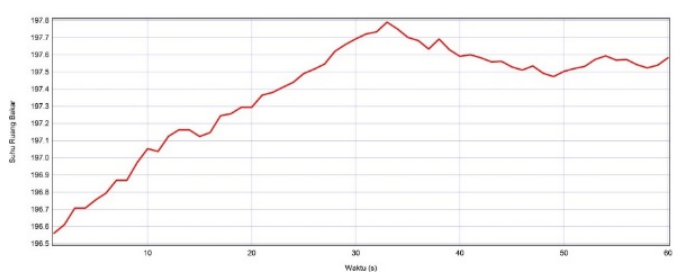

Gambar 3.22 Grafik temperatur ruang bakar Solar 100\% + HI-Cester vs waktu

\subsubsection{Pengujian Emisi Gas Buang}

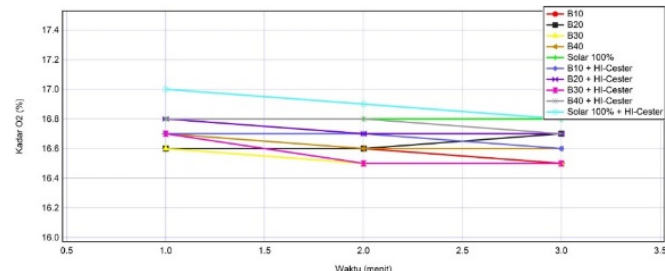

Gambar 3.23 Grafik $\mathrm{O}_{2}$ vs waktu

Kadar emisi O2 berbanding terbalik dengan kadar emisi CO2. Semakin tinggi keluaran O2 pada buangan, semakin kecil CO2 dan semakin kecil campuran udara-bahan bakar

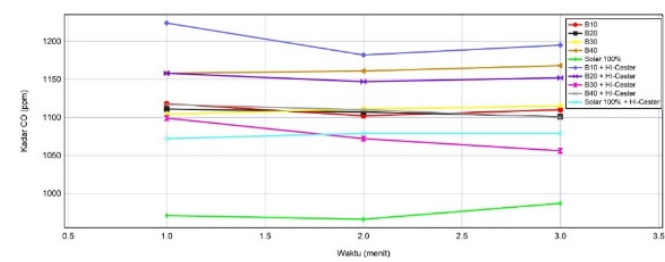

Gambar 3.24 Grafik CO vs waktu.

Emisi CO dipengaruhi oleh rasio udara-bahan bakar, semakin tinggi rasio udara-bahan bakar, maka semakin tinggi kadar emisi CO. Kadar emisi CO maksimum dihasilkan pada saat AFR tinggi, seperti mesin dinyalakan ada kondisi dingin atau ketika dipercepat.

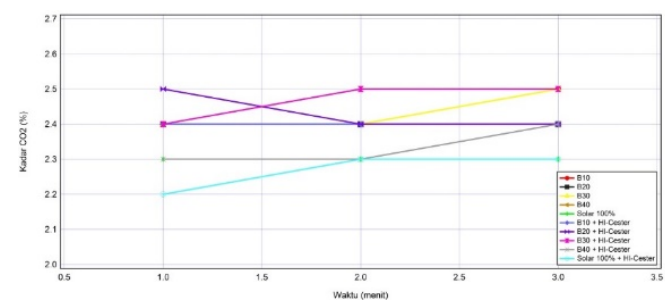

Gambar 3.25 Grafik $\mathrm{CO}_{2}$ vs waktu

Kadar emisi CO2 dipengaruhi oleh rasio udara-bahan bakar, kegagalan penyalaan, dan masalah mekanik motor. Kadar emisi CO2 tertinggi dihasilkan ketika rasio udara-bahan bakar ideal. 


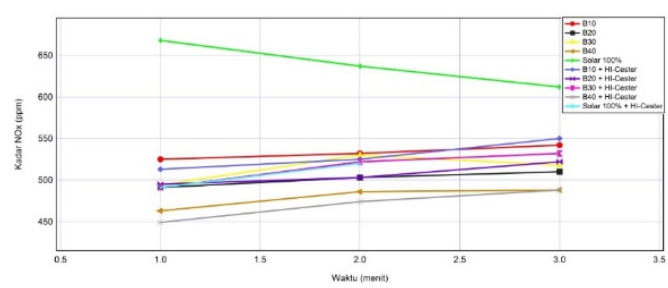

Gambar 3.26 Grafik $\mathrm{NO}_{\mathrm{x}}$ vs waktu

Kadar emisi NOx dipengaruhi oleh rasio udara-bahan bakar, dan waktu pembakaran.

Kadar emisi NOx maksimum terbentuk pada saat rasio udara-bahan bakar terjadi pada rasio kesetaraan.

\section{KESIMPULAN DAN SARAN}

\subsection{Kesimpulan}

Dari hasil pengkajian jika dibandingkan dengan solar murni didapat perubahan performansi mesin diesel menggunakan bahan bakar campuran biodiesel minyak canola dengan HI-Cester:

1. Daya menurun $8,7 \%$ - $26 \%$ jika campuran biodiesel semakin tinggi sedangkan daya meningkat 1,3\% - 7,5\% jika ditambah dengan HI-Cester.

2. AFR menurun $10 \%-12 \%$ jika campuran biodiesel semakin tinggi dan AFR tetap menurun $10 \%$ jika ditambah dengan HI-Cester.

3. Efisiensi volumetris menurun $2,4 \%$ - $12 \%$ jika campuran biodiesel semakin tinggi dan efisiensi volumetris tetap menurun 5\% - 9,7\% jika ditambah dengan HI-Cester.

4. Daya aktual menurun $19 \%$ - 33\% jika campuran biodiesel semakin tinggi sedangkan daya aktual meningkat 3,4\% - 4,3\% jika ditambah dengan HI-Cester.

5. Efisiensi termal aktual menurun 14\% - 20\% jika campuran biodiesel semakin tinggi sedangkan efisiensi termal aktual mengalami penigkatan $6 \%-9 \%$.

6. Konsumsi bahan bakar spesifik (SFC) meningkat 20\% - 28\% jika campuran biodiesel semakin tinggi sedangkan konsumsi bahan bakar spesifik meningkat 8\% - 13\% jika ditambah dengan HI-Cester.

\subsection{Saran}

1. Agar pemerintah Indonesia mulai mengembangkan penggunaan bahan bakar biodiesel kanola dikarenakan minyak kanola mudah didapat dan biodiesel kanola memiliki potensi besar jika dikembangkan.

2. Agar Departemen Teknik Mesin Universitas Sumatera Utara melengkapi alat uji kandungan emisi gas buang. Karena kendala terbesar yang dialami adalah pengadaan alat uji emisi gas buang. 


\section{REFERENSI}

[1] Pudjanarsa, Astu, dkk. 2008. Mesin Konversi Energi.

[2] Daryanto, Setyabudi. 2015. Teknik Motor

[3] Diesel. Bandung: Penerbit Alfabeta.

[4] Pulkrabek, W.W. 1997. Engineering

[5] Fundamental of the Internal Combustion Engine. New Jersey: Prentice Hall.

[6] Ambarita, Himsar., 2017. Termodinamika

[7] Teknik Fundamental dan aplikasi. Malang: Intelegensia Media.

[8] Setiawati, Edwar., (2007) Teknologi

[9] Pengolahan Biodiesel Dari minyak goreng Bekar Dengan teknik Mikrofiltrasi dan Transesterifikasi Sebagai Alternatif Bahan Bakar Mesin Diesel. Banjarbaru: Balai Riset dan standardosasi Industri.

[10] Peraturan Menteri Lingkungan Hidup dan

[11] Kehutanan Republik Indonesia No. P.20/MENLHK/SETJEN/KUM.1/3/2017 tentang Baku Mutu

[12] Emisi Gas Buang Kendaraan Bermotor Tipe

[13] Baru Kategori M, Kategori N, dan Kategori O

[14] Mofijur M, dkk. Ivestigation of exhaust from

[15] a stationary diesel engine fueled with biodiesel. Science Direct. Energy Procedia 160 (2019) 791-797.

[16] Al-Dawody Mohamed F., dkk. Experimental

[17] and simulation study for the effect of waste cooking methyl ester blended with diesel fuel on the performance and emissions of diesel engine. Science Direct. Alexandria Engineering Journal (2019) 58, 9-17. 